\title{
Mário-Alceu: um diálogo marginal (Mário de Andrade leitor de Alceu Amoroso Lima)
}

\section{Luciano Costa Santos ${ }^{1}$}

\section{Resumo}

A partir das anotações manuscritas por Mário de Andrade em seu exemplar da obra Mitos de nosso tempo de Alceu Amoroso Lima, o artigo visa reconstituir o diálogo do escritor modernista com as ideias do pensador católico, especialmente no que se refere à questão do catolicismo e de suas relações com o contexto histórico-cultural contemporâneo, destacando-se a surpreendente proposição, por parte de Mário de Andrade, de uma concepção de cristianismo presumidamente mais fiel às fontes evangélicas e, ao mesmo tempo, mais receptiva às influências da época moderna e da cultura brasileira.

\section{Palavras-chaves}

Catolicismo, cristianismo, modernidade, inculturação.

\section{Recebido 25 de novembro de 2008}

Aprovado 07 de julho de 2009

1 Professor de Filosofia na Universidade do Estado da Bahia (Uneb) e na Faculdade São Bento da Bahia (FSBB) e membro do Grupo Literatura e Sabedoria da USP, sob coordenação do Prof. Dr. Waldecy Tenório. E-mail: limasantosz@terra.com.br 


\section{Mário-Alceu: a marginal dialogue (Mário de Andrade as Alceu Amoroso Lima's reader)}

\section{Luciano Costa Santos}

\section{Abstract}

From manuscript annotations made by Mário de Andrade in his volume of Mitos de nosso tempo, written by Alceu Amoroso Lima, the article aims at rebuilding the dialogue between the modernist writer and the catholic thinker's ideas, especially focused on catholicism and its relations to cultural-historical contemporary context, highlighting the surprising proposition by Mário de Andrade of a conception of christianism presumably more faithful to evangelical sources and at the same time more receptive to influences from modern times and from the Brazilian culture.

\section{Keywords}

Catholicism, christianism, modernity, enculturation. 
A civilização vai mudar, Tristão. A Civilização Cristã chamada, e que eu não sei se algumas vezes V. não confunde um bocado com Cristo, está se acabando e vai ser um capítulo da História.

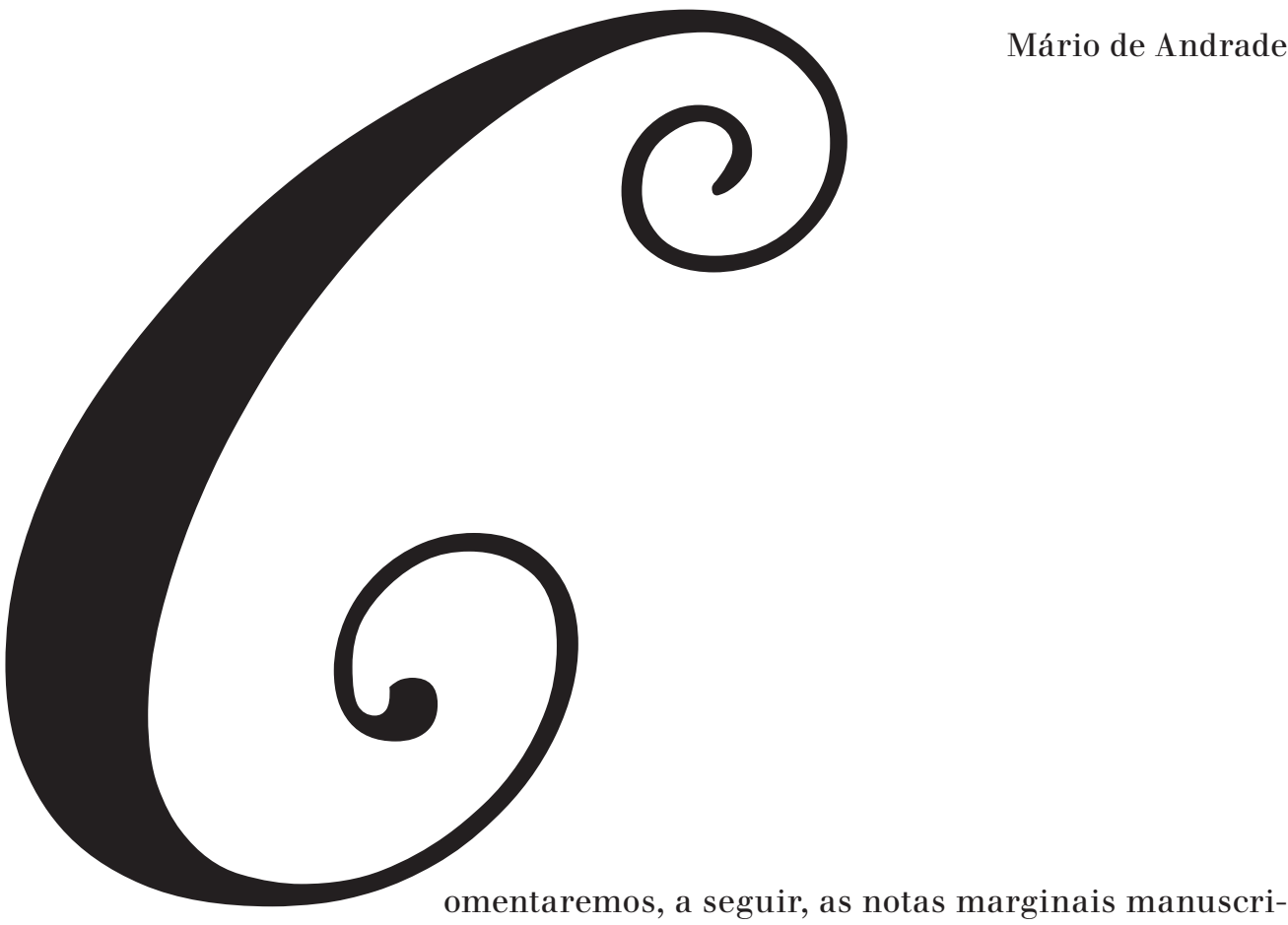
tas por Mário de Andrade em seu exemplar da obra Mitos de nosso tempo, de Alceu Amoroso Lima ${ }^{2}$. Como a íntegra das notas encontra-se à disposição dos leitores ${ }^{3}$, o presente comentário se limitará a uma exposição sumária das mesmas, seguindo suas principais linhas de recorrência, privilegiando a reconstituição do diálogo de pensamento de Mário de Andrade com Alceu Amoroso Lima - especialmente no que se refere à questão do catolicismo, aspecto dos mais agudos subjacente a Mitos e aos próprios comentários -, o que poderá abrir, segundo nos parece, uma nova e fecunda perspectiva de compreensão do próprio pensamento marioandradino.

Antes, convém apresentar um resumo das principais ideias constantes na obra Mitos de nosso tempo, sem o que não se terá o transfundo daquele diálogo de pensamento que aqui nos cabe reconstituir.

2 LIMA, Alceu Amoroso. Mitos de nosso tempo. Rio de Janeiro: Livraria José Olympio Editora, 1943.

3 N. E.: As notas encontram-se publicadas na seção Documentação dessa revista.

39

revista ieb $n_{49} 2009$ mar/set p. $x$-xx 


\section{Mitos de nosso tempo}

Alceu Amoroso Lima escreveu sua obra em 1942, em plena II Guerra Mundial ${ }^{4}$. Diante de um mundo "apaixonado e carnal”, propõe o que só se compreende "com o espírito sereno e a alma voltada para Deus", baseando-se no espírito de "distinção e justiça” para com ideias e homens (EMNT: 169). Entrevendo o advento de uma "idade nova" pósGuerra, reconhece que a solução por ele proposta para os novos tempos não é propriamente sua nem se restringe a sua época, tampouco se enquadra em qualquer estrutura política convencional (EMNT: 170). Para além das "estruturas superficiais", o autor visa "descer ao fundo das consciências e tocar o terreno humano e vital em que se processam as grandes transmutações", valendo-se da "inteligência normal", da "Fé autêntica" e da "experiência da história" (EMNT: 171).

Dizendo apoiar-se na "observação da natureza”, Alceu fundamenta o seu pensamento na "lei universal dos seres vivos" - a lei da ascenção e da decadência -, segundo a qual os seres oscilam, simultaneamente, entre dois planos que lhes são "imediatamente inferior e superior", prevalecendo a tendência ao plano superior. A essa lei o próprio homem permanece submetido, porquanto tende a "superar-se a si mesmo" pelo exercício de suas "faculdades superiores" (EMNT: 175). O que vale para os homens individualmente também se aplica às civilizações. Estas somente "se completam" quando chegam ao entendimento de que "a natureza do tempo é a imperfeição" e que "só a tendência à eternidade as eleva", não obstante ser o tempo não a "negação", mas apenas a "fase inicial" e a "face contingente" da "Realidade perene" (EMNT: 176).

O homem compõe-se de tempo e eternidade, sendo boa a vida em que vencemos as "contingências da matéria pelas permanências do espírito", embora em si mesmos nem a matéria - o que passa - é “o mal”, nem o Espírito5 é “o bem”, apenas encontrando-se "hierárquica e não niveladamente dispostos entre si”, pois no espírito se refletem "os valores autênticos da Eternidade", enquanto pela matéria "mais facilmente vai-se aos domínios destruidores do Efêmero.” Assim, a subordinação da matéria ao espírito ou a "procura do Eterno como medida do efêmero" é, nos planos

4. Em nosso resumo de Mitos de nosso tempo, utilizaremos o texto publicado em 1956 pela Editora Agir (Rio de Janeiro), incluído, juntamente com O existencialismo, no volume XVIII das Obras completas de Alceu Amoroso Lima, intitulado O existencialismo e outros mitos do nosso tempo. Portanto, na edição de 1956 o texto passa a chamar-se Mitos do nosso tempo, ao invés de Mitos de nosso tempo, como na edição de 1943 lida por Mário de Andrade. Doravante, o título desta obra será abreviado para EMNT.

5 A hesitação entre "espírito" e "Espírito" está presente no próprio texto de Alceu Amoroso Lima. 
individual e coletivo, a condição do "verdadeiro equilíbrio humano". O problema não está em viver com as coisas que passam, mas em supervalorizá-las como se fossem eternas; não está em "querer bem às coisas frágeis", mas em reduzir a vida à sua fruição (EMNT: 176-177). O erro reside, portanto, numa confusão ou indistinção dos valores, pela qual o tempo vem a erigir-se em "medida de todas as coisas" (EMNT: 178).

Em última instância, tudo tende à "ordem", "medida” e "distinção hierárquica de valores" que inclinam o homem ao "Absoluto através da relatividade". Com efeito, na natureza humana há uma "inclinação religiosa inata", consumação do instinto de conservação ou da tendência geral do ser a perdurar no ser (EMNT: 179). Quando a "noção normal de Absoluto" desaparece ou se atenua, dá-se o que o autor chama de "fenômeno de substituição". Originariamente, este reside no mecanismo pelo qual a vida - cujo elã de fundo é a própria busca de permanência - contorna um obstáculo à sua persistência (EMNT: 179-180). O progresso, por exemplo, não é senão uma "substituição de coisas inferiores" por outras superiores que garante a sobrevivência e expansão das civilizações (EMNT: 180).

Ora, o abuso da volúpia das coisas efêmeras e a fuga dos valores de permanência leva, no contexto social contemporâneo, à substituição como "compensação dos valores diminuídos" e é então que surgem os mitos (EMNT: 183).

O mito consiste na "atribuição de valor absoluto a uma entidade relativa", enquanto a mistica é a "dedicação passional a essa entidade relativa absolutizada". Toda mística é uma "atitude" (ou "meio") em vista de um mito correspondente. Sendo atribuição de valor, o mito implica atividade subjetiva; mas, correspondendo a certa realidade - intermediária entre a realidade em sentido próprio (independente do sujeito) e em sentido hipotético (existente apenas no sujeito) -, o mito também conserva algum estatuto objetivo. Subjetivo-objetivo, dinâmico, situado entre arte e ciência, o mito extrai, de sua própria ambiguidade, a força dogmática com que se impõe como "religião do século XX", sucedânea dos ceticismos científico e estético (EMNT: 186-188).

O mito é forma passional, "religiosa", de conhecimento. Comunica a elementos da realidade um valor absoluto que, de fato, não possuem, sendo assim mera "atribuição" - ao passo que a verdade é "descoberta" - de valor. O valor absoluto é medida dos demais; de natureza permanente, vale por si e só pode vigir fora da realidade contingente. Mas o mitologismo engendra, justamente, um "absolutismo relativista" que, admitindo embora o absoluto, projeta-o no âmbito da "relatividade passional", instaurando o "ciclo mágico de transmutação dos valores" (EMNT: 189-192). "Nova encarnação do Mistério”, o mito é o “deus dos incrédulos” (EMNT: 193). 
A mística é doação do próprio ser a outro considerado superior, pelo qual se vive e se morre. "Culto", "dedicação instintiva" e "obscura", a falsa mística dirige-se a entidades "abstratas" e "imanentes" - míticas -, assemelhando-se à possessão psicopática ou demoníaca, em que o sujeito perde o autodomínio e reduz-se à pura passividade. Ao valor relativo transmutado em absoluto chama-se "ídolo" (EMNT: 193-194).

Os mitos podem classificar-se quanto a sua importância, alcance e natureza. Quanto à importância, dividem-se em "capitais" - os que atingem maior número de adeptos, perduram por mais tempo e despertam sentimentos mais permanentes -; e "acidentais" - os que nascem e passam rapidamente. Quanto ao alcance, dividem-se em "universais" - os que se propagam por toda humanidade; e "locais" - os que se limitam à nacionalidade ou, nesta, a certas regiões. Em geral, os mitos capitais são universais e os outros, locais. Quanto à natureza, dividem-se em mitos de "ordem geral" - os que se referem a fenômenos da natureza humana em geral e tocam à personalidade; e de "ordem política" - os que se referem aos fenômenos da natureza social do homem e tocam à comunidade. Há, ainda, os mitos "permanentes" e os "temporários" (EMNT: 197-198). $\mathrm{O}$ autor enumera oito mitos contemporâneos capitais, sendo quatro de caráter geral - riqueza, técnica, sexo e cultura - e quatro de caráter político - classe, nação, raça e número (EMNT: 199).

Mito da riqueza: mais antigo e permanente de todos os mitos, encontra-se em declínio. Começa a invadir o Ocidente com o mercantilismo, alcançando, a partir do século XIX, domínio crescente sobre as consciências modernas, com o esplendor da civilização burguesa e a expansão do colonialismo. A fase socialista representa a "transformação" do mito burguês da "riqueza individual" em mito socialista da "riqueza coletiva". No entanto, o "fim completo do mito da pecúnia" seria a sua “correção pelo verdadeiro sentimento em face da fortuna”, subordinando-a aos valores humanos que lhe cabem (EMNT: 201-203). A riqueza converte-se em mito quando, de meio para alcançar fins superiores, é amada como fim em si mesma (EMNT: 203).

Mito da técnica: corresponde à fase socialista do fenômeno, verificado no mito anterior, de "predomínio do econômico sobre o social". Surge da evolução do domínio do homem sobre a natureza, particularmente a partir da Revolução Industrial e da mecanização, e articula-se ao mito do progresso. Implementado pela "mística da produção", para o autor, o socialismo - a que atribui certo "capitalismo socialista" - não representa o início de uma "nova civilização", mas o "fim” dessa "civilização naturalista" da qual é expressão o "culto da máquina". 
Mito do sexo: típico do século XX, apresenta-se sob os aspectos filosófico-científico e popular. Fundamenta-se na "psicologia sexualista" freudiana que dissocia, no instinto da vida, o prazer físico e a reprodução, e desdobra-se em um "culto fálico" disperso na ciência, na filosofia e nas artes. Reagindo contra o puritanismo do século XIX, o mito sexista acaba caindo, segundo o autor, no excesso contrário (EMNT: 213-217).

Mito da cultura: atribui valor absoluto ao trabalho do espírito humano. Radica no desligamento moderno entre as atividades da razão e da fé, desdobrando-se no movimento de independência absoluta das atividades do espírito contra a hierarquia religiosa, até o "humanismo ilimitado" de hoje. A partir de Descartes, as várias formas de intelectualismo levam a um subjetivismo que fecha o homem às verdades transcendentes, dando impulso a uma série de movimentos de emancipação - da filosofia face à teologia, da ciência face à filosofia, e da arte e da educação como fins em si mesmas ("arte pela arte" e absolutismo pedagógico, respectivamente) -, que são etapas do mesmo culto da cultura como atividade última do homem (EMNT: 219-226).

Mito do número ou mito democrático: o mais antigo e ambíguo dos mitos políticos, baseia-se no individualismo da civilização burguesa e decorre do choque entre os direitos da tradição e os direitos do número. Expressão política do surto capitalista, o regime democrático moderno se apoia na "vontade do grande número" e justifica-se pela "fé" de que a "salvação" dos povos está na aplicação do princípio da soberania do povo. Essa fé liberal desliga-se de qualquer subordinação ética ou religiosa e acaba fomentando a "onipotência da Opinião individual”. Embora no início do século XX o mito democrático encontre-se em vias de substituição pelo mito socialista, o que os aproxima, como aos demais mitos políticos do século, é a atribuição do caráter de "atividade suprema" à política (EMNT: 227-233).

Os mitos políticos seguintes - da classe, da nação e da raça - têm por base o ideal da revolução, cujos principais aspectos são a ruptura com o passado, a violência dos meios e a integralidade da transformação; a primazia do político ou do econômico sobre o cultural; e o messianismo político que divisa a "salvação da humanidade" - homem e civilização "novos" - a partir da Ordem Nova revolucionária (EMNT: 234-235).

Mito da classe: subjaz ao "socialismo integral" comunista. Baseado na luta de classes como lei fundamental da história, o materialismo histórico atribui valor absoluto à classe proletária enquanto condutora da revolução. Com o governo da coletividade pela coletividade, o mito classista tende à dissolução. Apesar de seu "messianismo mitológico", e de ser "ideal das massas" mais que sistema político-econômico, o comu- 
nismo inaugura um racionalismo materialista que promove a máxima exaltação da autoridade e da organização técnica. Baseada no sentido dogmático da vida e na intolerância, a mística revolucionária encontra no partido - expressão da classe e da revolução - seu mais autorizado porta-voz, convertido em "ídolo das massas".

Mito da nação: segunda das místicas totalitárias contemporâneas, o fascismo é o "erro político" que "prestou o serviço" de combater o também erro político comunista. Reafirmando suas "simpatias íntimas" pela causa das Nações Unidas, o autor repudia "toda espécie de totalitarismo" - fascista, nazista, comunista ou falangista -, mas recusa-se a ver a "sorte do mundo" dependente da opção democracia-totalitarismo. Para Alceu, a vitória das Nações Unidas é “tão necessária aos destinos da civilização" quanto a vitória dessas nações sobre os "regimes secularizados que elas absorveram em séculos de descristianização". Hibridismo político entre valores da ordem burguesa - pátria, família, religião etc. - e os métodos da ordem comunista - centralização, hierarquia, exaltação da classe proletária e do poderio militar -, o fascismo restaura o prestígio do poder na base do mito da nação, contraposto ao internacionalismo soviético. $\mathrm{O}$ imperialismo - outro aspecto da mística fascista - é "expressão natural” de toda "civilização poderosa" e deitou a perder a "função sadiamente reacionária" do fascismo contra a expansão, também imperialista, soviética (EMNT: 243-247).

Mito da raça ou do sangue: a raça é um valor defendido por correntes inspiradas no darwinismo naturalista do século XIX. Inicialmente, a Revolução Germânica assumiu caráter socialista, e não racista. As vacilantes condições de paz com os Aliados fizeram com que se formasse, na Alemanha, um partido irredentista fanático, baseado nos conceitos de chefe (encarnação e guia da coletividade), nacionalismo (a pátria como divindade) e socialismo (substituição da classe burguesa pela proletária). A estes, acrescenta o conceito de raça como elemento unificador da coletividade. Para o autor, o nazismo é o "mais perigoso" dos mitos da Idade Nova, ameaçando transformá-la numa volta à "Escravidão civilizada". "Não há nada de mais mortífero", com efeito, do que "a Técnica ao serviço do espírito de dominação" (EMNT: 249-254).

Aos mitos acima enumerados o autor contrapõe uma série correspondente de contramitos, que não são "mitos contrários", mas “o contrário do mito". Se o mito é uma atribuição de valor absoluto a entidades relativas, impõe-se a volta a uma "hierarquia de valores" que melhor corresponda à "natureza das coisas". O erro de seu tempo, segundo o autor, não está tanto "na escolha dos valores que preza", quanto no "modo de os classificar", tratando-se antes de um problema de "distribuição" que de "substituição" 
desses valores. Só há um "remédio radical" contra a mitologia moderna: a "restauração de uma concepção total da vida", em que cada coisa ocupe o lugar que, "por natureza", lhe é devido, cabendo preliminarmente recolocar em seu devido posto o "único valor absoluto". O problema fundamental do século não é, portanto, de ordem psicológica ou política, mas religiosa, atingindo os "fundamentos mais recônditos da vida individual do espírito". Sendo uma época "impregnada de religiosidade”, o século XX assiste a uma transmutação do "absolutismo" e do "dogmatismo" religiosos, no sentido que lhes conferem os novos mitos, e a uma volta aos mais "estranhos e contraditórios deuses" (EMNT: 259-260).

Assim, a "conversão fundamental" a fazer-se nesses tempos não é "do ceticismo à fé", mas da "idolatria mitológica" e da "afetividade mística sem aplicação" ao sentimento religioso "elevado à sua finalidade intrínseca", de ordem sobrenatural. Operada essa conversão, ficam a ciência, a filosofia e a arte liberadas para atingir a respectiva dimensão de verdade que lhes é própria (EMNT: 260-261).

À constatação da "incurabilidade dos mitos contemporâneos", o autor responde com a necessidade de opor contramitos inspirados em dois sentimentos básicos da vida cristã. O primeiro é o da "Parusia", pelo qual se compreende que o mundo caminha, não para a "realização de um progresso indefinido", e sim para a "volta de Cristo à terra". Contra a possível acusação de pessimismo, Alceu adverte que o cristianismo é a revelação da "solução de todas as contradições em que vivemos", embora nesta vida a "cura" seja sempre "relativa", pois "jamais se atingirá, sobre a terra, qualquer modalidade de paraíso." O outro sentimento é o de "Apostolado", espírito de "irradiação do Reino de Deus na terra", que impele à correção dos "males do mundo" pela "Caridade, material, moral ou intelectual”, sem jamais crer - e esse aspecto é fundamental para o diálogo que adiante consideraremos - em qualquer "utopia terrena" ou julgar que "o reino de Deus é deste mundo" (EMNT: 263-265). O desafio é, portanto, o de fazer "todo o bem que podemos", embora "cientes de que os males são inevitáveis” (EMNT: 265).

Em suma, na base do movimento contramitológico está uma volta “a Deus, a Cristo e à Igreja”. No mesmo plano social dos mitos contemporâneos, o autor sustenta ideais relativos que, justamente, atribuem "valor relativo e não absoluto aos valores adorados pelo homem moderno" (EMNT: 265-266).

Ao mito da riqueza, Alceu opõe o ideal da pobreza - que não é a "privação total de bens materiais" e, sim, o "desprendimento desses bens e a sua distribuição equitativa." O ideal de pobreza funda uma economia de "aproveitamento mais racional dos bens", de modo que atendam ao 
seu “destino próprio". A condição fundamental para colocar a vida econômica no posto que lhe cabe é orientar o homem a considerar os bens materiais não como fins em si, mas como "meios" a serviço de "fins superiores" (EMNT: 267-271).

Ao mito da técnica, o autor contrapõe o ideal do espírito. O sentido que orienta a superação do mito anterior é aqui retomado. Suposto que a técnica, como a riqueza, é um "bem em si", e que o progresso material da humanidade é fato desejável e irreversível, o ideal da técnica a serviço do espírito adverte que nem a técnica é finalidade em si, nem o progresso é suficiente para "assegurar a felicidade do homem". Assim, não deve o homem viver para a técnica, mas esta servi-lo, "colocando-se às ordens de uma vida em que os valores do espírito conservem a sua natural primazia" (EMNT: 273-275).

Ao mito do sexo, contrapõe-se o ideal do amor. "Mais alto exercício da vida humana", o amor é "desejo de fusão no objeto amado" e "tendência à fusão de todas as nossas faculdades". Considerado como fim em si mesmo, o sexo é "forma degradada de amor", servindo-se das criaturas ao invés de servi-las. Mas nada tem de censurável em si, sendo antes a "primeira forma de afirmação da plenitude do corpo humano". O que cabe, segundo Alceu, é reintegrar o sexo ao seu "verdadeiro rumo", conduzindo sua potência instintiva, pela temperança, ao "ideal de Pureza", dócil à "lei natural da fidelidade", pela qual "um corpo tende a um corpo.” (EMNT: 275-280).

Ao mito da cultura, contrapõe-se o ideal da verdade. Como nos mitos anteriores, também neste trata-se não de mover oposição ao valor absolutizado, mas de integrá-lo a uma nova concepção do humano. Neste caso, trata-se de integrar a cultura - a atividade do conhecimento - à verdade compreendida como "fusão" ou "adequação" do espírito com/ao ser. Sem essa correspondência ao ser, o espírito pode apropriar-se orgulhosamente do conhecimento como fim em si mesmo, até a "vertigem da cultura", cuja expressão mais conhecida é o diletantismo. Só a busca da verdade, que leva o homem do "culto a si mesmo" ao "culto autêntico a Deus", pode transformar o "culto da cultura" em atividade fecunda (EMNT: 280-284).

Ao mito do número, contrapõe-se o ideal da justiça. Conservando da democracia quantitativa o valor "substancial insubstitutível" da liberdade do indivíduo, o ideal aqui proposto assume-o como meio de alcançar os valores "mais altos" da verdade e do bem que, em matéria social, efetivamse como justiça, isto é, como a "proporção natural entre o que é devido e o que nos devem, entre as exigências de cada ser livre de acordo com a sua natureza e o seu procedimento" (EMNT: 286-287). Apenas sobre a justiça assim compreendida pode fundar-se o verdadeiro Estado de Direito. 
Ao mito da classe, contrapõe-se o ideal de cooperação das classes. Se para o autor a classe é uma "realidade social", o ideal de sua supressão após a "exaltação belicosa" da classe proletária reduz-se a "fantasia catastrófica". Ao "monismo" classista é preciso contrapor a "lei da variedade", segundo a qual "classes e profissões" são "realidades sociais intrínsecas" que correspondem a um "estágio avançado de progresso social”. Homens e famílias distribuem-se, "por natureza”, em classes, conforme o "modo do seu trabalho, o grau da sua cultura" e as "afinidades da sua psicologia". Reconhecidos a autonomia e os direitos de cada classe, cabe a estas o dever concomitante de respeitar os direitos das demais, sem o que não há paz social (EMNT: 293-295).

Ao mito da raça, contrapõe-se o ideal da família. Embora exalte a fecundidade e os laços de sangue, o racismo nazista não defende a família, mas o povo. Com efeito, a fecundidade que propugna é "meramente racial, governada pelo Estado" e visa à constituição de uma "Coletividade numerosa e forte" que realize o mito da dominação universal do Império nazista. Ora, a família é, "por natureza", o "fundamento da sociedade", por ser o "grupo vital por excelência” e, mesmo relativamente subordinada ao Estado enquanto este zela pelo bem comum, ela goza de autonomia intrínseca. Fundada na força do sangue transfundida em afeições "as mais profundas e inextirpáveis”, a família não nega a raça, apenas repõe-na em seu devido lugar (EMNT: 297-300).

Ao mito da nação, contrapõe-se o ideal da pátria. $\mathrm{O}$ autor parte do pressuposto de que o homem é um ser "essencialmente social" e "acidentalmente nacional", evitando uma divinização da comunidade nacional que a situaria para além das leis moral e divina. Reconhece, no entanto, a profundidade do sentimento nacional que, como Santo Tomás, denomina convivium e faz assentar na virtude da pietas, isto é, no dever de gratidão para com a pátria, da qual se recebe a base da formação material e humana. "Extensão" e, ao mesmo tempo, "meio natural” da família, a pátria suscita um amor filial semelhante ao que nos liga aos pais, sem que se possa confundilo com o sentimento religioso devido somente a Deus (EMNT: 316-319).

Concluindo, Alceu divide em duas as "grandes famílias de espírito" de seu tempo. Os "satisfeitos" acreditam que há uma "solução temporal para o drama deste mundo", creditando-a a um ou alguns dos mitos analisados. Os "insatisfeitos" não se conformam a quaisquer das soluções deparadas, havendo entre estes os "inquietos", cuja insatisfação ora desemboca em pessimismo generalizado, ora permanece na tensão de uma busca sincera e irresolvida; e os "cristãos", denominação "ambígua” e exigente com a qual o autor identifica a sua própria posição. 
Como se disse mais acima, mesmo acreditando não haver, "nesta vida", solução humana para os problemas do mundo - e por isso é inquieto -, o cristão acredita em solução para o mundo - e por isso também não é pessimista - fazendo-a residir na "volta ao Eterno", na "renúncia radical a todas as soluções temporais" e na "mudança completa do espírito". Oscilando entre a alegria de uma "presença infinita" e a desolação de uma "infinita ausência", a vida cristã é de ação constante "pelo Bem e pela Verdade" e, simultaneamente, de aceitação do fato de que, em última instância, o mundo é palco do "mistério da iniquidade" e a verdadeira vida esconde-se "na morte". A vida cristã encontra-se, portanto, a igual distância da "conformidade" e do "desespero" (EMNT: 325-329).

\section{As notas}

Dispondo apenas das margens laterais, superior e inferior da página para desenvolver-se, é próprio da nota marginal ser, em geral, tópica e concisa. Tópica, por deter-se nalgum destaque da página - parágrafo, trecho de parágrafo, frase, expressão ou mesmo vocábulo -, dispensando-se de dissertar sobre a estrutura da obra em seu conjunto. E concisa, colhendo em poucas palavras o essencial do que tem a dizer.

Reduzida às margens, a nota encontra-se destinada a tão-somente secundar a obra, comentando ou emendando aspectos, muitas vezes secundários, acrescentando dados, chamando a atenção, com sinais gráficos, para a relevância ou suposto equívoco de certos trechos, enfim, instaurando um diálogo marginal do autor das notas com o autor da obra.

Não obstante sua "marginalidade" física e sua relativa "secundariedade" de conteúdo, esse diálogo não será de somenos importância para o entendimento do percurso da obra do próprio autor das notas e, nesse sentido, pode ser visto como obra em si mesmo, a demandar sua própria chave de leitura ${ }^{6}$. Para tanto, cumpre tomar as notas em seu conjunto e verificar se daí ressaem núcleos conceptivos que contribuam para enriquecer a compreensão do pensamento de seu autor.

Ao todo, foram coligidas 41 notas manuscritas por Mário de Andrade às margens da obra Mitos de nosso tempo, de Alceu Amoroso Lima. À exceção da nota 41, redigida ao longo das duas páginas em branco seguintes ao fim da obra - como um pequeno balanço crítico desta -, as demais se contêm nas margens da página em que se iniciam ou, quando muito, prolongam-se até a(s) margem(ns) da página seguinte.

6 Cf. LOPEZ, Telê Porto Ancona. A biblioteca de Mário de Andrade: seara e celeiro da criação. In: ZULAR, Roberto (Org.). Criação em processo: ensaios de crítica genética. São Paulo: Fapesp; Iluminuras, 2002. 
Consideradas em seu conjunto, as notas de Mário de Andrade a Mitos de nosso tempo nos remetem aos seguintes núcleos conceptivos básicos: (1) reivindicação da primazia do Cristo sobre a cristandade; (2) crítica do "idealismo" subjacente à obra; (3) defesa do comunismo; (4) defesa de uma "espiritualidade terrestre".

\section{Cristo e a cristandade}

De aparição restrita no conjunto das notas, nem por isso este aspecto deixa de ser bastante significativo, quando se tem em vista a compreensão do pensamento marioandradino.

De modo geral, as críticas anotadas por Mário de Andrade em Mitos de nosso tempo não chegam a pô-lo em desacordo com os fundamentos cristãos-católicos da obra, a qual, na nota 41, o leitor reconhece "emaranhada em verdades incontestáveis - ou, simplesmente, na Verdade." Isto, aliás, confere com as inúmeras “confissões de fé” cristãs-católicas segredadas por Mário em sua vasta epistolografia ${ }^{7}$, em particular numa carta ao próprio Alceu - justamente naquela em que vaza toda sua amargura por ocasião da leitura de Mitos -, na qual chega a afirmar-se católico "com todas as fibras" de seu ser".

Por outro lado, também é certo que Mário de Andrade manteve-se distante das "leis sociais de catolicidade" e da "religião católica" enquanto "coletividade terrestre que guarda a Ideia católica"10 e, por isso, não ousava confessar-se católico em público - especialmente se o público representasse as "leis sociais de catolicidade" -, preferindo enquadrar-se em um "paracatolicismo" singularmente situado entre a mais pura ortodoxia em questões de fé e ousadias existenciais e artísticas dificilmente compatíveis com práticas e pruridos institucionais em voga na "coletividade terrestre" de seu tempo. Essa investidura "paracatólica" - menos "irresolução" que "positiva incapacidade para resolver-se" numa solução uniforme ${ }^{11}$ - assegurava ao homem e ao artista a liberdade para acreditar nas verdades fundamentais do catolicismo, sem deixar de dissentir do modo como estas eram interpretadas e institucionalizadas em seu contexto histórico.

Ora, é justamente quanto ao modo de professar o catolicismo que as notas de Mário de Andrade registram agudas dissonâncias em relação

7 Cf. SANTOS, Luciano. Elegia de Jacó, o homem (Mário de Andrade e a religião). In: . O passeio da coruja: ensaios filosóficos. Rio de Janeiro: Ed. Leviatã, 1994.

8 Apud FERNANDES, Lygia (Org.). Mário de Andrade escreve cartas a Alceu, Meyer e outros. Rio de Janeiro: Editora do Autor, 1968. p. 26.

9 Idem, ibidem, p. 26.

1o Cf. idem, ibidem, p. 33 .

11 Cf. SANTOS, Luciano. Elegia de Jacó, o homem. In: op. cit., p. 72-73. 
à obra de Alceu Amoroso Lima, sem, entretanto, saltarem propriamente para fora do elemento cristão-católico.

Aspecto significativo dessa dissenção, embora de ocorrência discreta, é a crítica de Mário a certa indistinção, supostamente subjacente à obra de Alceu, entre a mensagem do Cristo e a cristandade ocidental. Como se Alceu permanecesse aferrado a um modelo histórico de cristianismo, sobretudo o imperante na Idade Média, a ponto de, por vezes, acabar sobrepondo-o ao próprio Evangelho ${ }^{12}$. Curiosa correção: aqui, o "paracatólico" Mário de Andrade move-se no sentido de uma recuperação das fontes cristãs, contra a própria "ortodoxia" do católico Alceu ${ }^{13}$.

$\mathrm{Na}$ nota 4, por exemplo, face à afirmação de que "o mitologismo não é apenas a religião de nossos tempos, mas ainda a de todas as épocas históricas em que se desintegra uma civilização", Mário comenta:

[...] o autor não está mais estudando e julgando enquanto filósofo e sociólogo, mas em função do seu Catolicismo. De um catolicismo que julga a chamada (meu Deus!) 'Civilização Cristã', como tendo alcançado o seu apogeu na Idade Média. Isto é: uma civilização não mais definida e compreendida pelo que é, em si, mas como expressão da doutrina de Cristo. Ora, não há dúvida que o Cristianismo, ou melhor, Cristo, deu origem a uma civilização. Mas da qual, em seguida, ele não teve a culpa!

Em sentido inverso, Mário também não concorda que o Renascimento seja considerado inferior, como civilização, à Idade Média “cristã”,

12 Cabe ressalvar que essa quase indistinção entre Cristo e cristianismo ocidental, criticada por Mário de Andrade em Mitos, caracteriza o período pós-conversão de Alceu Amoroso Lima que se estende dos anos 1930 a meados da década seguinte, sendo desde então gradualmente superada por uma nova experiência de fé que, não obstante permanecesse vigorosamente cristã e católica, já mostra importantes reservas críticas em relação à cristandade medieval e à neocristandade do Concílio de Trento e, por extensão, a qualquer concepção eclesiológica ou política que leve a confundir a autoridade espiritual da Igreja e o poder temporal, como se pode constatar, dentre outros exemplos, pela oposição do mestre católico aos regimes totalitários "cristãos" de Franco e Salazar. Esse aggiornamento do apostolado de Alceu (que a morte precoce não permitiu que Mário testemunhasse) terá presença marcante na sociedade brasileira, em especial após o golpe militar de 1964 .

13 Esse contraste entre o Cristo e a cristandade reponta ao longo da obra marioandradina, a exemplo dos seguintes versos de "Lira paulistana": "São glórias desta cidade/ Ver a arte contando história/ A religião sem memória/ De quem foi Cristo de verdade [...] Isso é glória?" (In: ANDRADE, Mario de. Poesias completas. São Paulo; Belo Horizonte: Edusp; Ed. Itatiaia, 1987. p. 36o); e: "Eu me vejo sozinho, arrastando sem músculo/ A cauda do pavão e mil olhos de séculos, / Sobretudo os vinte séculos de anticristianismo/ Da por todos chamada Civilização Cristã...” (Idem, ibidem, p. 392). 
o que a seu ver é "simplesmente confundir civilização e cultura (Kultur, sociologicamente) com uma determinada religião".

Na nota 21, à margem da afirmação de que Hitler, "vindo do nada", como Mussolini, Lenin e Stalin, teve a "vantagem da aventura pura" para a "tarefa revolucionária”, o leitor comenta: "Queria muito saber o que pensaria disto o filho de carpinteiro de Nazaré. Mas o A. não só confunde Cristo com Civilização Cristã (I. Média), como não raro prefere esta a Aquele.”

Na mencionada carta-desabafo a Alceu, Mário leva mais longe sua posição crítica face à cristandade:

A civilização vai mudar, Tristão. A Civilização Cristã chamada, e que não sei se algumas vezes $V$. não confunde um bocado com Cristo, está se acabando e vai ser um capítulo da História. Tão lindo como o dessas igualmente nobilíssimas civilizações da Antiguidade, o Egito, a China, a Grécia. Com a Cristã nós demos um passo a mais, apenas um passo a mais do amelhoramento terrestre do homem e da sociedade humana. Se nem tudo foi pra melhor, o todo foi incontestavelmente pra melhor. E a civilização que vem ainda há-de ser fatalmente um passo a mais, e um todo melhor. Tudo isto nada tem a ver com o outro mundo. Nem eu sei nem quero a morte da Igreja imortal e o desaparecimento da religião nem a sempre por demais próxima chegada do Anticristo. Mas não haverá o perigo pra muitos e pra você, de preferir a Igreja a Deus? ${ }^{14}$

Ao relativizar o monopólio histórico da cristandade ocidental sobre o Evangelho, o escritor forceja pela recuperação do sentido originário deste, mas também pela instauração de novas possibilidades de inculturá-lo. Enseja uma volta ao Evangelho que seja, ao mesmo tempo e com igual força, recriação do Evangelho a partir de sua encarnação em novos tempo e lugar. Reivindica, em certo sentido, mais fidelidade espiritual e mais liberdade histórica - atitudes claramente contrastantes, mas nem por isso contraditórias entre si. A segunda dessas atitudes se insinua já em $A$ arte religiosa no Brasil, escrito de juventude no qual o congregado mariano, depois de deplorar o erro brasileiro de "construir igrejas nos mais estrangeiros dos estilos", e de constatar que a religião "entristeceu-se", deseja que a Igreja "nos dê ainda templos nossos, capelas brasileiras onde a comoção religiosa da raça palpite, como num lar avoengo"15.

14. Apud FERNANDES, Lygia (Org.), op. cit., p. 33-34.

15 ANDRADE, Mário de. A arte religiosa no Brasil. São Paulo: Ed. Experimento, 1993. p. 92. Grifo nosso. 
Nesse sentido, sem deixar de confessar-se católico, o pensamento de Mário de Andrade aspira ser, a um só tempo, mais cristão e mais pluralista, face ao modelo de cristandade herdado da Europa.

\section{Crítica do idealismo}

Em certa medida, este núcleo conceptivo já se acha entranhado no anterior. Com efeito, a julgar pelas notas, a primazia conferida por Mitos à cristandade ocidental - em particular à Idade Média - como modelo trans-histórico de civilização cristã se apoia em um pensamento generalizador que recusa o enfrentamento acurado dos fatos para confirmar ideias e ideais já supostos. Referindo-se à parte da obra consagrada aos "contramitos", o leitor assim o registra, na nota 26 :

De resto, o mal demagógico infelizmente revestido de Cristianismo, ou simplesmente de Filosofia, de toda a pregação idealista desta parte, é que o A. não enxerga o homem, mas sonha com o Homo. E o que é mais idílico, mas apenas idílico, um Homo dotado de historicidade, um sonho do Homo pré-renascente, pré-rafaelista, ao mesmo tempo que esquece toda a história do homem anterior a Cristo e posterior à Civilização Cristã. Nunca o A. abusou tanto da verdade e da filosofia pra criar um sonho não apenas improvável: absolutamente vão.

Assim, ao idealizar a cristandade medieval, o autor de Mitos incorreria, segundo seu crítico, em um duplo equívoco: o de ignorar os limites históricos da própria cristandade e o de desconsiderar as possibilidades humanizadoras das demais civilizações "anteriores a Cristo e posteriores à Civilização Cristã”, entre as quais estaria a própria civilização brasileira, ainda em gérmen, para cuja consolidação histórica Mário de Andrade dedicou sua vida e sua obra, trabalhando, sobretudo, em campo cultural e estético.

Noutro momento, essa atitude generalizadora é reconhecida por Mário como traço definidor da personalidade intelectual de Alceu, a contrastar com a sua própria:

[...] eu como todos os sutis decadentes tendo necessariamente a distinguir, a ser um analítico, e você como todos os ditadores, condutores etc. tende necessariamente a englobar e a ser sintético. Eu vejo na síntese, não uma imbecilidade, mas certamente uma primaridade que sob o ponto-de-vista da realidade é falso. Você vê 
na análise, um minuete a perder tempo e Verdade em gazes, sedas e supérfluos, que sob o ponto-de-vista da mesma realidade (isso é que é espantosamente admirável) é falsa. ${ }^{16}$

Mas a crítica de Mário de Andrade ao "idealismo" de Mitos não se restringe ao campo propriamente religioso.

Em campo histórico, por exemplo, na nota 10, face à exaltação do "surto grandioso de idealismo democrático" norte-americano que "levantou um povo penetrado de comodismo e devorado pelo mito da técnica”, o leitor anota: "Eis o tipo do que seja fazer história idealista: sem Pearl Harbour e o mito da traição, sem a ‘atrapalhação' que o Eixo estava trazendo aos interesses econômicos dos EEUU, queria ver o ianque 'levantado'”.

Em campo moral, na nota 23, Mário chama a atenção para a afirmação de que "o pudor é um dos mais nobres atributos da mulher, por estar naturalmente adequado à sua natureza específica”, e comenta: "Tudo isto é a ignorância voluntária do quanto se tem estabelecido de 'verdade' a respeito do pudor na natureza humana. Mas o cômico é que pro A. o pudor não é um ‘atributo' do ser, mas da mulher!” Como não ver aqui uma antecipação dos versos de "Meditação do Tietê" que ironizam "os mariscos, as ostras e os trairões fartos de equilíbrio e Pundhonor. Pum d'honor"? Talvez nessa idealização com forte acento moralizante se encontre um dos mais significativos aspectos daquelas "leis sociais de catolicidade" de que o escritor, como boa parte dos artistas modernos de seu tempo, havia-se afastado.

Em campo social, na nota 24, ao arrazoado de Alceu segundo o qual

Não é o número de escolas, nem o número de livros, nem a quantidade maior ou menor de analfabetos que marca a colocação de um povo na escala da civilização. É a qualidade dos seus homens. E a natureza de sua cultura, na hierarquia natural dos valores.

o leitor reage:

Tudo isto é de um confusionismo... É possível a um analfabeto, por ex., atingir esta "qualidade" que o A. deseja aos homens!... É o próprio São Tomás, numa frase de horrenda e trágica verdade, que já nos disse atrás que pra o homem conseguir uma vida moral, precisa de um certo número de bens materiais.

16 Apud FERNANDES, Lygia (Org.), op. cit., p. 26. 
Embora invoque aqui o doutor da Igreja, em posições como esta o pensamento de Mário de Andrade já mostra franca convergência com as grandes linhas do materialismo histórico marxista, cuja reiterada defesa - em nível, sobretudo, político - constitui, justamente, um dos núcleos conceptivos das notas, como se verá a seguir.

Na nota 27, outra vez em campo histórico, como o autor pondere que "existe um semitismo tão racista como o germânico e tão místico, como o antissemitismo", o comentarista exclama:

Oh, meu Deus! Mas que generalização malvada! E sectária! Não nego um semitismo, mas o A. nega toda a história nesta igualação, palavra-de-honra, desavergonhada! Mas a Idade Média é uma espécie de ideal para o A., como lembrar os guetos?

Em suma, na nota conclusiva, Mário de Andrade assim resume a limitação de fundo contida na atitude de Alceu: "O autor avisa e sabe que uma civilização nova está nascendo. E, idealistamente, não cuida de orientá-la, a nega." Residiria aí aquela "falta de fecundidade terrestre e social" que, na mesma nota, o leitor atribui ao pensamento do escritor católico, como veremos mais adiante.

\section{Defesa do comunismo}

Sua forte sensibilidade social, a índole confessadamente "analítica", voltada para o exame atento dos fatos e de suas causas, e a tendência particularmente "socializante" dos anos que se seguiram à Revolução de 1930 fizeram com que Mário de Andrade acabasse se inclinando ao marxismo e, mesmo, simpatizasse com o comunismo soviético, ao qual só não aderiu formalmente, como confessa na citada carta de 1943 a Alceu, por medo de inutilizar-se "num qualquer tiro de esquina"17.

Esse veio socializante (que já repontara no jovem poeta de "Há uma gota de sangue em cada poema") acabou por fomentar em sua obra uma importante viragem paradigmática, a partir da qual um mais amplo e humano interesse artístico passa a prevalecer sobre o desinteresse estético e a suplantar qualquer resquício formalista de "arte pela arte". A ideia de "interesse artístico" reconhece que, embora moldada em linguagem estética e destinada à fruição estética, a arte é - como tudo o que pertence ao homem - movida originariamente por paixões e ideais humanos e, como tal, também deve ser considerada. Assim, chega a ser

17 Apud FERNANDES, Lygia (Org.), op. cit., p. zo. 
artisticamente legítimo o sacrifício da liberdade estética quando estão em jogo demandas ético-sociais inescusáveis. Dessa viragem paradigmática é testemunho maduro a ópera $O$ café, concluída em 1942, na qual "a perversidade impiedosa da ideia definidora por exagero" faz-se acompanhar da "perversidade tosca da voluntária imperfeição estética"18.

Embora se refira a um tema de ocorrência restrita no conjunto da obra de Alceu Amoroso Lima, a defesa do comunismo mobiliza uma quantidade relevante de notas, e notas especialmente vigorosas, em que a crítica muitas vezes atinge as raias da indignação. Em parte, esse peso se explica pelo calor da hora, já que, durante a leitura de Mitos, a Segunda Guerra atingia o seu apogeu, o regime soviético despontava como o mais sólido oponente militar à ameaça nazista e, em termos ideológicos, como a única alternativa consistente ao capitalismo norte-americano.

Na nota 7, à tese de que "é nos povos penetrados da mística revolucionária e para quem a Revolução é um Mito, que o culto da máquina se desenvolveu [...], em virtude justamente do grande atraso mental das populações", Mário rebate:

Tudo isto [...] é absurdo, duma facilidade larvar. Os russos careciam se defender. Todo o mundo estava e está contra a URSS. Haviam de atirar trigo e florinhas silvestres contra balas de canhão, bloqueio econômico e o diabo? E como o autor acomoda o caso do Japão, faz mais de século?!...

Na nota 11, ante a afirmação de que "a mística revolucionária" cria "um novo-homem e uma nova civilização. E sobre ambas repousa a salvação da humanidade", o leitor sublinha o último período e comenta: "Exagero de uma parcialidade de sectário. O A. confunde ou finge confundir a ideologia comunista com a demagogia comunista. E 'salvação da humanidade' é o que propõem todas as demagogias."

A nota 12 refere-se ao parágrafo em que, dissertando sobre a expansão soviética, Alceu sustenta que "só as circunstâncias porém, e as alianças obrigam [o Estado soviético] a um recuo de publicidade que é de ordem puramente estratégica" e que, "nem por isso", Stalin "perde a vantagem adquirida de uma mística que avassalou e galvanizou todo um povo e lhe permitiu realizar façanhas militares extraordinárias [...].” Comentário de Mário: "Tudo isto vem sendo de uma insensibilidade, de uma incompreensão, de uma falta de Charitas, francamente primárias. E totalitarismo do miúdo." Muito interessante que o leitor invoque "Charitas" - a maior das virtudes teologais do Evangelho - para emendar o juízo do autor católico.

18 In: ANDRADE, Mário de. Poesias completas, op. cit., p. 421. 
Ante a consideração de que o fascismo "nasceu como reação contra o comunismo" e que é "nesse ponto que se baseia um dos elementos diferenciais com que devemos julgá-lo com objetividade e sem paixão", a nota 15 repara: "Agora o A. reclama para si o dever de julgar com objetividade e sem paixão..." - o que, por suposto, ele não teria feito ao analisar o comunismo.

No capítulo sobre o mito da nação, Alceu afirma que os comunistas "costumam atribuir ao termo e ao fato do imperialismo uma origem e uma função de caráter capitalista”. Comentário na nota 17:

Eis o que é paixão partidária e sectarismo. Não é falso. Ou melhor: é mentira. Um comunista chamará também de manifestação imperialista a conquista da Etiópia. Mas o A. que tudo sumariza, aqui se arrepela com um conceito "histórico" e resolveu "distinguir".

No mesmo parágrafo, à tese segundo a qual "O imperialismo é uma expressão natural de todo ser, individual ou social, de toda personalidade forte e de toda civilização poderosa", Mário reage:

É inconcebível a leviandade do A. aqui, que o induz a um erro latifundiário. Dando exemplos verdadeiros e criminosos, o A. justifica [termo sublinhado] o imperialismo como "expressão natural de todo ser individual ou social"!!! O imperialismo não deriva de uma expressão natural do ser, mas do crime do "lobo e o cordeiro". Não é uma "expressão", é uma "deformação". Onde ficou Cristo! Onde ficou o Sermão da Montanha! Onde ficou o "a César o que é de César"!

Na nota 18 - retomando o sentido da nota 15 -, após sublinhar o trecho "Ainda é cedo, naturalmente, para julgar acontecimentos tão próximos a nós", referente ao fascismo, Mário anota:

É psicologicamente concludente que ao atacar o Comunismo o A. nenhuma vez se preocupasse em ser honesto e justo e capaz de distinguir, e agora [em vista do fascismo] se refira tantas vezes a essas exigências do verdadeiro espírito filosófico.

Na nota 26, como Alceu sustente que o "pan-eslavismo" se "integrou na Revolução Comunista", a ponto de confundir-se "com o sovietismo", o leitor se indigna:

Aqui a injustiça da generalização chega ao absurdo, a não ser que o A. esteja mentindo - o que talvez seja preferível imaginar! Dar 
ao sovietismo "caráter essencialmente racista" e o que é mais idiota pan-eslavista, o confundir com o pan-germanismo racista, que o A. insiste em justificar (é o termo doloroso) como nascido de uma necessidade contra a Revolução (quando ele mesmo lhe reconheceu causas de origem histórico-psicológicas): tudo isso é confundir atualidade histórica com falsa profecia.

A nota 29 refere-se à afirmação de que a tendência soviética a "equiparar filhos legítimos, naturais e até adulterinos" é "francamente totalitária”. Comentário: “É preceito simplesmente cristão, que, aliás, como igualdade humana, nada tem a ver com a Família, nem a destrói." Este comentário é muito sugestivo: mostra que, ao aproximar-se do comunismo, nosso paracatólico não somente ainda se reconhece radicado em elemento cristão, como em certo sentido parece encontrar neste elemento a inspiração de fundo para aquela aproximação, como se o comunismo explicitasse em teoria social "germens de verdade" que originariamente pertenceriam à própria revelação cristã. ${ }^{19}$

Tendo em vista a observação de que "[...] a Igreja Católica, a quem caberia por direito divino a prioridade e a univocidade no governo espiritual da sociedade, vê-se hoje forçada pelas circunstâncias a reivindicar apenas a sua liberdade contra os seus inimigos [...]", Mário comenta na nota 31: "Eis que o A. se torna histórico, relativista e pragmático. E se quer filósofo em busca da Verdade.” Portanto, o autor se investiria aqui, ao abordar a Igreja, de uma atitude compreensiva que houvera recusado ao analisar o comunismo.

\section{"Espiritualidade terrestre"}

Eis que chegamos ao mais importante dos núcleos conceptivos das notas, e à nota mais importante - e conclusiva.

De fato, este núcleo conceptivo só encontra desenvolvimento explícito, a rigor, na nota 41. Trata-se, entretanto, de uma nota diferente das demais, pois o que nela vem anotado não é, como foi dito mais atrás, nem conciso nem tópico, antes se desenvolve ao longo de duas páginas como uma exposição crítica do próprio conjunto e estrutura da obra comen-

19 Aludimos aqui à doutrina do logos spermatikós ("sementes do Verbo"), concebida por Justino - um dos precursores do pensamento cristão ocidental -, segundo a qual toda verdade que se possa encontrar em culturas e doutrinas desenvolvidas à margem da Revelação judaico-cristã se deve à participação destas no Espírito Santo (ou Verbo de Deus) que, à sua própria revelia, nelas infunde sementes da verdade que somente na Revelação atingem sua plena realização. 
tada. Por outro lado, neste aspecto das notas, vem à luz, pela primeira e única vez, a dimensão positiva e propositiva do pensamento de Mário de Andrade em relação ao que lhe parece mais problemático na obra de Alceu Amoroso Lima.

Na nota 41, assoma sem peias e a plena voz não somente uma crítica, mas uma recusa e mesmo rejeição de aspectos da obra de Alceu que ferem profundamente a sensibilidade do leitor. A indignação e a quase revolta registradas na nota encontram franca confirmação na citada carta de Mário a Alceu, de 17/6/1943, que, a julgar pelo tom e pelo conteúdo das críticas, talvez não exagerássemos em ler como uma antecipação da própria nota, considerando ter sido escrita dois meses antes desta. De resto, redigida a menos de três anos da morte do escritor, essa nota guarda importante valor documental, senão testamental, para o estabelecimento de seu pensamento tardio.

A nota 41 é, de certo modo, preparada pelas três notas precedentes. Nestas, sinais de exclamação, apostos à margem de trechos em destaque, fazem soar o alarme para aspectos problemáticos que, justamente na nota conclusiva, acabarão por ser explicitados e respondidos.

Na nota 38, Mário apõe três exclamações à margem do trecho:

E todo aquele que não se sentir totalmente ausente de tudo o que for apenas deste mundo não conhecerá jamais a doçura da verdadeira paz do espírito, nem o segredo das relações verdadeiras e salvadoras. A vida está na morte, a riqueza na pobreza, a vitória na derrota, a fecundidade dos frutos no apodrecimento das sementes.

Na nota seguinte, uma exclamação chama a atenção para o trecho:

Quando propomos, portanto, os contramitos contra os mitos que dominam os nossos tempos, não temos a mínima ilusão de poder conseguir, com eles, uma Idade Nova paradisíaca para o dia em que a Guerra terminar [...]. As civilizações serão eternamente uma vaga e remota imagem de um Reino que não é deste mundo.

$\mathrm{Na}$ nota 40, o leitor exclama à margem do fragmento sublinhado: "[Contra o orgulho e a vaidade dos Mitos do nosso tempo, tenhamos a] coragem invencível e a paciência dos que vivem na Alegria perfeita da renúncia."

Na própria nota 41, em continuação lógica das sinalizações anteriores, é sublinhado o trecho: "Porque a herança do Pecado feriu de morte todas as almas, até a liquidação dos tempos.” Comentário do leitor: 
Eis no que dá uma atitude “cristiânica” (não, de Cristo), regularmente... luterana até e pelo menos muito pascaliana [fragmento riscado] diante do terrível problema da realidade terrestre do homem social. [...] Como negar que o apostólico A., se colocando bonitamente entre os insatisfeitos, no fundo é um satisfeito, e um fatalista. É quase repulsivo observar como o A. insiste, no meio de suas tiradas fatalistas sobre a felicidade e o Bem Supremo não serem deste mundo, é quase repulsivo observar como, sem a menor ordem lógica de pensamento, ele volta a falar nos mitos e no combate aos mitos [...]. Uma como consciência pré- ou supraconsciente de que estava fora do assunto, fora da atitude lógica, fora da Filosofia.

Ressaltam aqui: (1) a questão nodal em torno à qual se dá o embate do leitor com a obra, a saber: "o terrível problema da realidade terrestre do homem social"; (2) a atitude ou perspectiva do autor da obra, segundo o leitor - “cristiânica (não, de Cristo), regularmente... luterana até” -, valendo frisar como o paracatólico Mário de Andrade reivindica outra vez aqui o "Cristo" contra a atitude supostamente "cristiânica” do autor, isto é, erigida em nome de Cristo e derivada de sua palavra, mas não de todo fiel ao seu espírito, atitude que Mário inclusive situa fora do próprio elemento católico, ao caracterizá-la como "regularmente... luterana até". Enfim, salta do comentário acima a (3) posição atribuída pelo leitor ao autor da obra - "fatalista", sendo que mais abaixo ele a caracteriza como "pietismo quase supersticioso", por afirmar não serem "deste mundo" a "felicidade e o Bem Supremo".

Lembremos que a posição cristã-católica, tal como a compreende Alceu Amoroso Lima em sua obra - apoiado aqui nos dogmas do pecado original e da redenção -, enfeixa uma dialética indissolúvel: de um lado, reconhece que o mundo está submetido ao mal, não sendo possível ao homem, em definitivo, remi-lo por suas próprias forças; de outro, afirma o poder redentor de Cristo sobre o mal, embora ressalve que essa redenção só possa consumar-se na vida eterna. Nessa perspectiva, o cristão vive a tensão de uma inquietude que não chega a converter-se em pessimismo devido à fé na redenção, e de uma esperança que não se converte em otimismo devido à lembrança do mal. Como apóstolo da redenção, ele é instado a - como vimos na exposição resumida de Mitos - "procurar sempre corrigir os males do mundo pela Caridade" e a "fazer todo o bem" possível, mas a constatação do pecado original o leva simultaneamente a denegar "qualquer utopia terrena" e a crença de que seja dado ao ser humano o poder de edificar o Reino de Deus, em definitivo, "neste mundo". 
Parece claro que, em si mesma, esta posição nada tem de "pietista" nem induz ao "fatalismo". Trata-se tão-somente da articulação viva e tensa de dois princípios fundamentais da fé cristã-católica, e o próprio Mário admite, como vimos, estar a obra de Alceu "emaranhada em verdades incontestáveis - ou simplesmente, na Verdade", e "muito bem alicerçada em sã filosofia". No entanto, se em seus comentários o leitor não parece querer desatar essa dialética subjacente a uma fé de cujos aspectos fundamentais ele não se mostra absolutamente disposto a dissentir - antes pelo contrário -, o que assim mesmo motiva sua recusa indignada dos supostos "pietismo" e "fatalismo" da obra de Alceu é, segundo nos parece, o fato de, para Mário, essa obra carregar uma ênfase desmedida ou inoportuna na dimensão vertical-espiritual da mensagem cristã - a relação pecado-redenção, consubstanciada no sentido escatológico da Parusia ${ }^{20}$-, quando para o escritor modernista tratava-se antes de enfatizar a dimensão horizontal-social do Evangelho, referente ao apostolado do cristão junto a e com as forças deste mundo.

Esse aspecto de ênfase, que joga com a dimensão histórica e estratégica do cristianismo, é insinuado por Mário de Andrade ao menos em dois lugares fora dos comentários a Mitos. Primeiro, na própria carta a Alceu, de 17/6/1943, num longo trecho onde o escritor afinal descarrega sua insatisfação com a obra do colega:

Seu livro não é pros que estão do outro lado! Seu livro não é pra mim! E quando, depois de expor os mitos, V. me vem com aquele capítulo preliminar, dizendo que preliminarmente é preciso acreditar em Deus, senão tudo o que V. vai dizer não pode ser aceito [...], eu fico desesperado, com vontade de não acreditar em Deus. E é trágico, Tristão. É trágico menos por mim que Deus zurze incessantemente e maltrata com suas graças, e eu imagino que escolheu para que morra nele: é trágico mas para os sem-deus mas espíritos nobres, boa gentinha universitária, cheia da sensualidade de viver (sem Deus nem chateações), mas cheia da dignidade também, dignidade que lhe dá uma vaga derradeira esperança... E vejo esses moços se atirarem sobre o seu livro querendo sem simpatia, saber, querendo ver, capaz de ver, pronta pra ver, principiar o seu livro gostando, vai gostando... No dia seguinte é este moço que me chega abespinhado, o mais próximo do Catolicismo, tornado o mais longínquo, porque você terminou seu livro, afinal das contas conferindo que este mundo é um vale de lágrimas e o prêmio está no outro

20 Cf. LIMA, Alceu Amoroso. O existencialismo e outros mitos do nosso tempo, op. cit., p. 328-329. 
mundo do paraíso! Bolas! Meu caro Tristão! bolas!... Não sei se isto agora é o apostolado de Paulo, se ele estivesse no mundo atualmente e nos escrevesse a "Epístola para os Para-Católicos".

Mais adiante:

Mas não sou eu que tenho importância, no caso, há coisas, há vida, há um amelhoramento da sociedade humana, há todo um futuro neste mundo que, não você por fraco, mas o Catolicismo por tibieza estão descuidando. Em proveito do outro mundo? É neste mundo que nós temos que forçar a ação da graça. ${ }^{21}$

Como se vê, ao lamentar o embaraço dos jovens com o livro de Alceu, Mário acusa a incapacidade da obra de falar ao seu tempo; acusa o cristianismo da obra - não obstante sua coerência com os próprios postulados - de descompasso com o espírito de seu tempo. Um cristianismo que só consegue fazer sentido para dentro de si mesmo, no diálogo dos iguais entre si. É isto o que motiva a grita de Mário, ele que, no plano cultural e estético, como "papa do modernismo", sempre tivera voz altissonante entre os jovens, mas cujo paracatolicismo não o autorizava a falar em nome de uma fé e de princípios espirituais que, entretanto, continuava tendo em alta consideração: o que motiva sua grita é a ânsia, afinal frustrada pela obra de Alceu, de que a mensagem cristã-católica pudesse ainda falar aos espíritos de seu tempo.

$\mathrm{O}$ outro lugar em que se justificaria, ainda que indiretamente, a ênfase estratégica sobre a dimensão horizontal-social do cristianismo, é a afirmação da conferência sobre o modernismo, de 1942, de que "vivemos uma idade integralmente política da humanidade" 22 . Se assim é, caberia ao cristianismo buscar em sua palavra aquelas dimensões humanistas de sentido que pudessem responder aos desafios "políticos" de seu tempo.

Assim - continua o leitor de Mitos, na nota conclusiva -, "a verdadeira atitude católica social, não pode nunca ser condicionar a vida terrestre a uma imperfeição irremediável e ao 'Pecado que feriu de morte todas as almas'. É inaceitável esta atitude conformista, fatalista e... burguesa [...]”.

Segundo Mário - e aqui afinal aparece o vetor propositivo de seu comentário -,

21 Apud FERNANDES, Lygia (Org.), op. cit., p. 32-33.

22 ANDRADE, Mário de. Aspectos da literatura brasileira. 5. ed. São Paulo: Livraria Martins Editora, 1974. p. 255. 
como verdade apostólica a atitude católica tem de ser democrática: a Igreja não pode abandonar os seus direitos sobre as sociedades dos homens. É a atitude de Maritain e é a verdadeira. E como verdade tout court, que não deixa de ser também católica, é uma atitude de ação, como diz o A., mas que não pode preliminarmente contar com a precariedade terrestre do homem, embora saiba dela.

"Embora saiba dela", isto é: o leitor admite a "precariedade terrestre do homem" - o pecado original -, mas não considera lícito pôr a ênfase sobre ela a ponto de inibir ou anular a "atitude de ação" implicada, de modo imperativo, na dimensão humano-social da profissão de fé católica.

Continua Mário:

A ação, o Bem, é atingir a perfeição social. A perfeição - sem imaginar que ela não pode ser alcançada. O homem indivíduo tem como absoluto dever moral atingir o Bem, ou mais completamente, a Perfeição que inclui a Verdade e o Belo. Pouco importando a revelação de que isso é um prêmio da vida futura. O homem social tem esse mesmo absoluto dever moral em relação à sociedade $\mathrm{e}$ à Terra. A Lei admirável e inefável é que não há (não devia haver...) acomodações com a Igreja. Tudo o mais é conformismo e fatalismo pietista. E um idealismo empalamado. Livro que causa um malestar enjoativo. Não pelo que recusa, quase sempre. Mas, quase sempre, pelo que aceita.

Portanto, a questão da relação do homem com a "realidade terrestre" não se põe, em primeiro plano, em termos da possibilidade ou não de vir a consumar o Reino de Deus neste mundo, mas em termos da responsabilidade humana de colaborar para a realização do Reino - "sem imaginar" que a perfeição "não pode ser alcançada" e "pouco importando a revelação" de que ela "é um prêmio da vida futura". A responsabilidade só atinge sua estatura propriamente humana se é gratuita e a fundo perdido, não visando outra coisa que a realização do bem por si mesma ${ }^{25}$.

Por outro lado, a desconsideração da possibilidade de alcançar a "Perfeição" como prêmio futuro parece-nos soar menos como indiferença pela vida eterna do que como atitude preventiva contra aqueles "pietismo" e "fatalismo" que, em nome da realidade do pecado original e da esperança na salvação eterna, acabam por imobilizar o homem em uma espera esca-

23 A tese da transcendência de sentido e da gratuidade inscritas na responsabilidade ética constitui um dos aspectos centrais do pensamento do filósofo judeu Emmanuel Levinas. Cf. Totalidade e infinito. Lisboa: Edições 7o, s.d. 
tológica sem fim, desmotivando-o a lutar pela realização do bem a partir de e neste mundo. Em termos teológicos, Mário estaria advogando o papel co-redentor do homem na realização da obra de Deus, papel irrevogável e que, sendo integralmente humano e temporal nos recursos, alcança ser, ao mesmo tempo e com igual força, divino e eterno em seu significado. Nesse sentido, a "teologia" subjacente às notas, se é lícito nos exprimirmos nesses termos, carrega um forte acento judaizante, ao menos na medida em que a missão co-redentora do homem na história, e toda a dimensão social da realização do Reino de Deus, constituem aspectos decisivos da espiritualidade judaica de todos os tempos, o que menos significa reivindicar uma herança judaica sobre o pensamento de Mário de Andrade do que reconhecer um poderoso veio judaizante intrínseco a sua formação cristã-católica. Em perspectiva histórica, essa vertente acabaria recebendo significativa implementação teológica no interior da própria tradição católica, com o Concílio Vaticano II e as conferências episcopais latinoamericanas e, mais recentemente, com a Teologia da Libertação.

Enfim, essa espiritualidade terrestre, horizontal, antropológica, que reponta na nota 41, encontra-se difusa no próprio evolver da obra de Mário de Andrade e, a nosso ver, é fomentada ao menos por três linhas de força convergentes e, em certa medida, superpostas.

A primeira linha de força inerente à espiritualidade terrestre de Mário de Andrade consiste no que mais acima já se chamou de tendência socializante do pensamento marioandradino, de aparição precoce em sua obra, acentuada nos anos trinta e levada ao paroxismo durante a Segunda Guerra, até a morte do escritor. Trata-se muito simplesmente da ideia de que o ser humano está votado a falar e a servir à comunidade humana, e que sua obra - artística ou qualquer outra - não pode encerrarse como fim em si mesma, à margem dessa destinação, sem trair-se. Sem pretendermos verificar essa tendência socializante da obra de Mário de Andrade por um recorrido biográfico que nos levaria muito além dos limites deste trabalho, lembremos, entretanto, o fato muito significativo de que o apostolado do jovem Mário na Igreja Católica começa com sua admissão na Conferência Vicentina, fundada por Frederic Ozanam, cujo carisma abrangia o apostolado junto aos jovens, a atividade intelectual e, justamente, o compromisso do serviço social ${ }^{24}$.

A segunda linha de força da espiritualidade terrestre de Mário de Andrade consiste no que, noutra carta a Alceu Amoroso Lima, de 23/12/1927, ele denomina "dionisismo", isto é, "não só uma vontade de gozar a vida, porém o gozo da vida", que o faz prender-se "por um entusiasmo de corpo e alma pelos movimentos da vida" e vivê-los "com uma

24. Cf. SANTOS, Luciano. Elegia de Jacó, o homem. In: op. cit., p. 65. 
intensidade pasmosa". Dionisismo "sem êxtase, uma confiança sensual, uma fé sistematizada em tudo, e uma certeza permanente e perdoadora na imbecilidade do homem", que "vibra" em "toda" sua obra ${ }^{25}$.

Essa "confiança sensual" - não ideologia da "eterna alegria", mas o puro dom de gozar a vida ${ }^{26}$-, para a qual "a própria dor é uma felicidade", leva o escritor a simpatizar desde cedo com Epicuro, impulsiona em certa medida a estética libertária de "Paulicéia desvairada" e, mais tarde, se projetará na dimensão telúrica e solar de Macunaíma, cujas aventuras “de sarapantar" não transparecem apenas falta de caráter psicológico e moral, mas, também e justamente, gozo da vida, pletora vital, glorificação da existência terrena. Como proclama o poeta em "Paulicéia desvairada", "Sou um tupi tangendo um alaúde!" (O trovador) ${ }^{27}$, e não é outra senão essa dimensão visceralmente indígena, aborígine, telúrica, de sua personalidade, que leva Mário de Andrade a consagrar-se, na segunda fase modernista, a uma mística da brasilidade, movido por "fome", e "positivamente fome física, estomacal"28, "de Brasil", na sôfrega aspiração de integrar-se às raízes ancestrais de sua terra e de seu povo. Ora, é amplificando-se em um "tropical amor do mundo" 29 e num "tudoamor"

25 Apud FERNANDES, Lygia (Org.). 7I cartas de Mário de Andrade. Rio de Janeiro: Livraria São José, s.d. p. 17-18.

26 Cf. Idem, ibidem, p. 17.

27 ANDRADE, Mário de. Paulicéia desvairada. In: Poesias completas, op. cit., p. 83.

28 Cf. ANDRADE, Mário de. Cartas de Mário de Andrade a Luis da Câmara Cascudo. Belo Horizonte: Ed. Villa Rica, 1991. p. 35.

29 "Eu não vos convido sequer à felicidade, pois que da experiência que dela tenho, a felicidade individual me parece mesquinha, desumana, muito inútil. Eu vos quero alterados por um tropical amor do mundo, porque eu vos trago o convite da luta. Permiti-me a incorreção desta vulgaridade; ela porém não será talvez tão vulgar, pois que não vos convido à luta pela vossa vida, nem à caridosa dedicação pela vida enferma ou pobre, mas exatamente a luta por uma realidade mais alta e mais de todos." E: "Eu vos trago o presente perfeito da imediata luta por uma realidade mais de todos. Há toda uma mística nova a envergar sobre os ombros, para que o destino não se desvirtue na procura mesquinha do nosso bem pessoal. Não desprezo o indivíduo e sei glorificar as criações, as forças e riquezas de que só ele é capaz: porem foram tais os descaminhos humanos na exaltação egoística do indivíduo, que nos vemos num momento agro do mundo em que qualquer idealidade tem de equiparar-se à religião, cujo resultado é fundir." Portanto, ao invés de visar a mera intensificação e expansão da alegria (individual) de viver, o "tropical amor do amor" a que se refere Mário implica alteração dessa alegria numa outra: a de lutar para que todos tenham direito à vida, e em seu sentido mais "alto". Trata-se, pois, de um chamado a transmutar o prazer de viver em prazer de partilhar a vida, isto é, a transmutar o eros telúrico em caritas cristã, cujo sentido se analisará logo em seguida e que, para Mário, está longe de reduzir-se à "caridade" assistencialista tal como praticada pela cultura católica de seu tempo. ANDRADE, Mário de. Oração de paraninfo. In: Aspectos da música brasileira. Belo Horizonte: Ed. Villa Rica, 1991, p. 195. Grifos nossos.

$3^{0}$ "Nos Pirineus em pororoca prodigiosa/ Rompe a consciência nítida: EU TUDOAMO." ANDRADE, Mário de. O carro da miséria. In: Poesias completas, op. cit., p. 283. 
ção da vida terrestre em todas as suas dimensões e, em particular, da vida social neste lugar - o Brasil - e neste tempo - o moderno - que lhe ocorria habitar, que o mencionado "dionisismo" da personalidade de Mário de Andrade transmuta-se em espiritualidade terrestre e, de certo modo, vem a justapor-se, e às vezes até a superpor-se, à tendência socializante de seu pensamento, acima considerada.

Por fim, a terceira linha de força subjacente à espiritualidade terrestre de Mário de Andrade é o que aqui denominaremos teologia da Caritas, e que talvez mais não seja senão a transfiguração, em plano teológico, do dionisismo recém descrito. Caritas, no sentido cristão, vem a ser a terceira e mais importante das "virtudes teologais", isto é, daquelas virtudes somente passíveis de serem exercidas se a pessoa se encontra em estado de graça, sob ação direta do Espírito Santo. Se a fé e a esperança são, respectivamente, o modo como o homem crê e espera em Deus em meio à sua condição mortal (e por isso essas virtudes estão destinadas a desaparecer na vida eterna), Caritas é o próprio amor de Deus agindo no homem, o ato de amar a vida tal como Deus a ama e, nesse sentido, é a eternidade agindo como obra temporal. Caritas não desaparece na vida eterna, pela simples razão de que a vida eterna é a plenitude mesma de Caritas - em suma, "Deus é Caritas". Ora, se a insistência na fé e na esperança poderia vir a abrigar, clandestinamente, uma atitude espiritual conformista, que tudo espera de Deus e somente d'Ele, a ênfase (outra vez a ênfase) sobre Caritas apela para que o homem já se reconheça chamado, nesta vida, a agir como Deus age, a amar como Deus ama, a redimir como Deus redime, a consagrar-se, portanto, à vida terrena como uma espécie de emissário do Eterno.

Essa ideia é bem explicitada em carta a João Etienne Filho, de 10/2/1944, um ano antes de sua morte, quando Mário diz não ter "piedade cristã, enquanto virtude pretendida", porque "é tamanho o meu interesse pessoal, o meu amor pela, digamos, utilização de mim mesmo, que tudo se transforma para mim numa luta esportiva mas bravia, em que decerto eu perco dez ou trinta jogos, pra ganhar um". Mais adiante, defende para o cristianismo de seu tempo um curioso "martírio esportístico", martírio

com muita saúde de espírito, mais por interesse de vida que por interesse de morte, que pusesse de parte a Esperança, com menos Fé que Caridade, capaz de amar a Deus não sobre todas as coisas, mas nas coisas, capaz de amar a Deus cegamente na obra de Deus [...]".31

31 SANTOS, Luciano. Elegia de Jacó, o homem. In: op. cit., p. 69-7o. Grifo nosso. 
Na citada "Oração de paraninfo", essa apologia de Caritas retorna sob outro ângulo:

[...] O que eu indigito como espécie de nossa incultura, é este viver dentro da morte, esse desgalhamento da visão católica do outro mundo, que nos leva a uma caridade assustada, a uma caridade supersticiosa, a uma caridade esquecida de que a própria vida é uma oração. Ninguém aceita a vida como um benefício de Deus. Ninguém aceita a vida como uma luta, mas como um perigo de ir pro inferno. ${ }^{32}$

Deixando em aberto a discussão sobre a pertinência das críticas de Mário de Andrade aos supostos "pietismo", "fatalismo" e "conformismo" contidos na obra de Alceu Amoroso Lima, o que aqui nos parece mais significativo é o fato de o seu confronto com as ideias do pensador católico acabar ensejando uma oportunidade privilegiada para a exposição de suas próprias concepções a respeito da questão religiosa e de outras afins. Desse embate, ressalta uma surpreendente reivindicação, por parte do escritor paracatólico, de retorno às fontes cristãs para aquém/além do modelo histórico da cristandade ocidental e, também, sua iniciativa de ousar reinterpretar - horizontalmente - essas fontes a partir do novo lugar hermenêutico instaurado por sua condição moderna e brasileira, emergindo daí uma nova mística, cristã e tropical, a um tempo profundamente humano-social e telúrica.

Assim, a discussão marginal (não apenas em sentido bibliográfico) travada por Mário de Andrade com a obra de Alceu Amoroso Lima aponta para a imprevista possibilidade de que a fidelidade à mensagem do Cristo seja concebida de modo a conciliar-se com a exigência de permanente renovação de sua institucionalização histórica, o que, de um lado (e principalmente), se justifica pela transcendência de sentido da Boa Nova cristã - irredutível a qualquer tradução sociocultural - e, de outro, por sua constitutiva abertura aos diferentes lugares e tempos em que ela é chamada a encarnar-se. Nesse sentido, certa "paracatolicidade", certo posicionamento "além" e "à margem” do lugar religioso instituído, tal como o viveu e suportou Mário de Andrade, talvez não deva ser entendido somente como um estratégico distanciamento adotado pela sui generis profissão de fé do homem-artista modernista face à "catolicidade" vigente em seu meio social, com seus apertados preceitos e pré-conceitos, mas também como sinal de uma vitalidade espiritual u-tópica inscrita na condição peregrina da própria fé cristã católica.

32 ANDRADE, Mário de. Oração de paraninfo. In: Aspectos da música brasileira, op. cit., p. 191. Grifo nosso. 